\title{
PENGEMBANGAN KARIER PEGAWAI NON MEDIS (Studi Deskriptif Kualitatif di RSUD Dr. M. YUNUS BENGKULU)
}

\author{
Haryati Utami \\ Program Studi Manajemen Fakultas Ekonomi Universitas Dehasen Bengkulu \\ haryati_utami90@yahoo.co.id
}

\begin{abstract}
ABSTRAK
Haryati Utami; Tujuan dari penelitian ini adalah untuk mendeskripsikan peran individu, peran manajemen dan peran organisasional terhadap pengembangan karir tenaga medis di lingkungan Dr. M. Yunus dari Bengkulu. Metode data yang digunakan adalah observasi, kuesioner dan wawancara. Penelitian dilakukan dengan menyebarkan kuesioner kepada 40 orang tenaga medis di lingkungan Dr. M. Yunus dari Bengkulu. Dalam penelitian ini juga diwawancarai 5 pimpinan kabupaten. M Yunus dari Bengkulu sebagai cross check hasil kuesioner yang dihasilkannya. Penilaian data dan data. Data asesmen dan data data dan data datanya. Hasil Penelitian ini menunjukkan peran individu, peran organisasi dan peran manajemen telah memberikan kontribusi terhadap pengembangan karir pekerja non medis di Dr. M. Yunus dari Bengkulu. Berdasarkan hasil penelitian dalam hal peran individu, personil medis non-medis perlu ditingkatkan kesadaran yang diberikan disamping tenaga medis di kabupaten. M. Yunus dari Bengkulu harus lebih aktif mencari informasi tentang pengembangan karir. Dalam aspek peran manajemen, kepemimpinan harus terus didukung dan tenaga kerja non medis di Dr M. Yunus Bengkulu dan pimpinan dan diharapkan dapat terus mengkomunikasikan misi, kebijakan, dan informasi informasi agar tercipta peningkatan. Dalam aspek peran organisasi, Dr. M. Yunus dari Bengkulu harus menyediakan fasilitas dan fasilitas pelatihan yang mendukung pengembangan karir personil non-medis. Selain itu, sebaiknya Dr. M. Yunus dari Bengkulu harus merancang sebuah program khusus untuk mendukung pengembangan karir personil non-medis.
\end{abstract}

\begin{abstract}
Haryati Utami; The purpose of this study is to describe the role of individuals, management roles and organizational roles towards career development of medical personnel in Dr. M. Yunus from Bengkulu. Data method used is observation, questioner and interview. The research was carried out by distributing questionnaires to 40 non medical personnel in Dr. M. Yunus from Bengkulu. In this study also interviewed 5 leaders of the district. M Yunus from Bengkulu as cross check the results of the questionnaire that produces. Assessment data and data. Assessment data and data data and data data. Results The study demonstrates the role of individuals, the role of the organization and the role of management has contributed to the career development of non medical workers in Dr. M. Yunus from Bengkulu. Based on the results of research in terms of the role of individuals, non-medical personnel hospital needs to be increased awareness given in addition to medical personnel in the district. M. Yunus from Bengkulu should be more actively seeking information about career development. In the aspect of the role of management, leadership must be continuously supported and non medical labor in Dr M. Yunus Bengkulu and the leadership and is expected to continue to communicate the mission, policy, and information information in order to create increased. In the aspect of organizational role, Dr. M. Yunus from Bengkulu must provide training facilities and facilities that support the career development of non-medical personnel. In addition, it should be Dr. M. Yunus from Bengkulu should devise a special program to support the career development of non-medical personnel.
\end{abstract}

Key words: individual roles, management role, organization roll, career development

\section{PENDAHULUAN}

Pegawai atau karyawan harus dipekerjakan secara efektif, efisien, dan manusiawi karena merekalah sumber daya yang dimiliki organisasi, mereka. Dalam perkembangannya, organisasi akan menghadapi permasalahan tenaga kerja yang semakin kompleks. Oleh karenanya pengelolaan tenaga kerja sebagai Sumber Daya Manusia (SDM) harus dilakukan secara profesional oleh departemen tersendiri dalam suatu organisasi, yaitu Human Resource Departement (HRD). Organisasi harusnya tidak akan mengabaikan aspek pengembangan kualitas SDM-nya supaya tetap eksis dan memiliki citra positif di mata masyarakat. Oleh karena itu, peranan manajemen SDM dalam organisasi sangatlah besar. Salah satu bagian manajemen SDM adalah pengembangan karier dari SDM sebagai tenaga kerja, pegawai ataupun karyawan itu sendiri.

Karier merupakan faktor yang mendorong kemauan kerja seseorang yang tergolong kebutuhan yang harus terus ditumbuh kembangkan dalam diri seseorang tenaga kerja. Pengembangan karier harus 
dilakukan melalui penumbuhan kebutuhan karier tenaga kerja, menciptakan kondisi dan kesempatan pengembangan karier serta melakukan penyesuaian antara keduanya melalui berbagai mutasi personal (Wahyudi, 2002:161). Untuk pencapaian karier yang diinginkan membutuhkan waktu dan proses yang cukup panjang. Dalam pengembangan karier di RSUD Dr. M. Yunus Bengkulu tentunya proses pengembangan karier para pegawainya bukanlah semata-mata karena nasib, akan tetapi masih banyak faktor yang berperan penting seperti peranan individu, manajemen, dan organisasi terhadap pengembangan karier pegawai di RSUD Dr. M. Yunus Bengkulu.

Dalam proses meniti jenjang karier dibutuhkan perencanaan sejak dini dan dapat juga dijadikan sebagai motivasi dalam bekerja untuk meningkatkan prestasi kerja, karena apabila seorang pegawai menduduki jabatan yang lebih tinggi tentu persepsi orang lain, ia memiliki prestasi yang baik sehingga ia dapat menduduki jabatan tersebut. Dengan adanya perencanaan karier yang baik, maka seseorang akan dapat menentukan langkah apa yang harus dilakukan untuk meraih jenjang tertentu. Misalnya bila persyaratan untuk duduk sebagai Kepala Bagian (Kabag) minimal berijazah sarjana, maka setiap karyawan yang ingin menjadi Kepala Bagian (Kabag) tersebut mestinya mempersiapkan diri sebelumnya untuk dapat meraih jenjang yang diinginkan.

Berdasarkan pra penelitian atau pengamatan awal, terdapat fenomena yang ada di RSUD Dr. M. Yunus Bengkulu, ada pegawai non medis yang memiliki prestasi yang bagus, kinerjanya tinggi, namun kariernya berjalan ditempat atau tidak pernah berubah. Untuk itu muncul pertanyaan, mengapa demikian? Hal ini disebabkan pegawai tersebut tidak memanfaatkan kesempatan untuk melanjutkan pendidikan kejenjang yang lebih tinggi karena pegawai tersebut tidak mempunyai biaya untuk melanjutkan pendidikan tersebut. Sedangkan dari RSUD Dr. M. Yunus Bengkulu tidak menyediakan dana bantuan untuk pendidikan lanjutan tersebut. Bukankah dijelaskan bahwa untuk meraih karier yang lebih tinggi, seorang pegawai harus mampu mewujudkannya melalui jenjang karir. Untuk mencapai pengembangan karier pegawai, maka dapat ditinjau dari beberapa aspek yaitu, peran individu, peran manajemen, dan peran organisasi.

\section{Teori Karier}

Menurut Flippo (1995) karier dapat didefinisikan sebagai suatu rangkaian kegiatan yang terpisah tetapi berkaitan, yang memberikan kesinambungan, ketentraman, dan arti dalam hidup seseorang. Selanjutnya menurut Gibson et al (2000) karir merupakan urutan pengalaman dan kegiatan yang berkaitan dengan pekerjaan dan yang menciptakan sikap dan perilaku tertentu pada diri seseorang. Menurut Handoko (2000) karir adalah seluruh pekerjaan atau jabatan yang ditangani atau dipegang selama kehidupan kerja seseorang. Suatu karir terdiri dari urutan pengalaman atau suatu rangkaian kerja yang dipegang selama kehidupan seseorang yang memberikan kesinambungan dan ketentraman sehingga menciptakan sikap dan perilaku tertentu.

Dalam kesempatan lain Handoko (2000:123) mengemukakan karier adalah sernua pekerjaan atau jabatan yang ditangani atau dipegang selama kehidupan kerja seseorang. Dengan demikian karier menunjukkan perkembangan para pegawai secara individual dalam jenjang jabatan atau kepangkatan yang dapat dicapai selama masa kerja dalam suatu organisasi. Selanjutnya menurut John dan Osborn, (1997:74) karir adalah serangkaian pilihan dan kegiatan pekerjaaan yang menunjukkan apa yang dilakukan oleh seseorang untuk dapat hidup). Sedangkan menurut Poerwadarminta (2000:111) dalam Kamus Umum Bahasa Indonesia, karir adalah kemajuan dalam kehidupannya; perkembangan dan kemajuan dalam pekerjaan, jabatan dan sebagainya; misalnya karir itu dicapainya dengan bekerja keras dan berdisiplin.

\section{Pengembangan Karier}

Menurut Tohardi (2002:218), pengembangan karier adalah keseluruhan jabatan yang dipegang seseorang selama orang tersebut bekerja. Selanjutnya, menurut Hasibuan (2001:69), pengembangan karier adalah suatu usaha untuk meningkatkan kemampuan teknis, teoritis, konseptual dan moral pegawai di rumah sakit sesuai dengan kebutuhan pekerjaan/jabatan melalui pendidikan dan latihan.

Pengembangan karier (seperti promosi jabatan) sangat diharapkan oleh setiap pegawai. Pengembangan karier lebih merupakan suatu pelaksanaan rencana karier pada kenyataan dilapangannya, seperti yang diungkapkan oleh menurut Handoko (2000: 123), pengembangan karier adalah peningkatanpeningkatan pribadi yang dilakukan seseorang untuk mencapai suatu rencana karier.

Menurut Harsoyo (1997) dalam kaitannya dengan organisasi juga sudah mempunyai program tersendiri dalam mengembangkan karier pegawai di rumah sakitnya yang sama dijabarkan secara deskriptif dan umum. Adapun yang dimaksud manajemen karier adalah manajemen kepegawaian dimana untuk pengangkatan pertama didasarkan atas kecakapan, sedangkan dalam pengembangan selanjutnya, 
masa kerja, pengalaman, kesetiaan, pengabdian, dan syarat- syarat objektif lainnya. Harsoyo (1997) juga mengatakan bahwa uraian analisis diatas yang dimaksud pengembangan karier adalah suatu pendekatan atau kegiatan yang tersusun secara formal untuk meningkatkan pertumbuhan, kepuasan kerja, pengetahuan dan kemampuan pegawai di rumah sakit agar organisasi dapat memastikan bahwa orangorang dengan kualifikasi dan pengalaman yang cocok tersedia dalam organisasi. Pembinaan karier dan penilaian sistem prestasi kerja dan sistem pengembangan karier pada Pegawai Negeri Sipil melalui kenaikan pangkat, mutasi jabatan serta pengangkatan dalam jabatan.

\section{Peran Dalam Pengembangan Karier}

Dalam proses pengembangan karir individu dalam organisasi, ada 3 hubungan saling terkait antara individu, pimpinan (manajer), maupun organisasi. Ketiga-tiganya memiliki peran masing-masing. Dessler (2007:8) meninjau pengambangan karier dari aspek-aspek sebagai berikut:

\section{Peran Individu dalam Pengembangan Karier}

Pengembangan karier individu memerlukan individu-individu yang memahami kebutuhan akan pengetahuan, prestasi, kemampuan dan golongan pribadi. Menurut Otte dan Hutchenson (Dessler, 2007) menyatakan bahwa peran individu dalam pengembangan karier berupa :

- Mengemban tanggung jawab atas karir Anda sendiri.

- Menilai minat, keahlian, dan nilai-nilai.

- Mencari informasi informasi karir dan sumber daya.

- Menyusun tujuan dan perencanaan karier.

- Manfaatkanlah kesempatan pengembangan.

\section{Peran Manajemen dalam Pengembangan Karier}

Menurut Otte dan Hutchenson (Dessler, 2007) menyatakan bahwa peran manajer (pimpinan) dalam pengembangan karier berupa:

- Berikanlah umpan balik kinerja yang tepat waktu.

- Berikan dukungan dan penugasan yang membangun.

- Berpartisipasilah dalam diskusi pengembangan karir.

- Dukung rencana pengembangan karir.

Manajer harus mampu meningkatkan motivasi pengembangan karier bawahannya. Manajer dapat merangsang semangat bawahannya dalam rangka memaksimalkan kinerja karyawan. Pada umumnya karyawan cenderung dapat bekerja dengan maksimal apabila manajer dapat memberikan stimulus dan bimbingan untuk pengembangan karier bawahannya. Pemberian reward dan promosi jabatan dapat menjadi salah satu alternatif untuk memberikan umpan balik bagi karyawan yang tepat waktu dalam penyelesaian tugas. Hal ini dapat merangsang keinginan karyawan untuk meningkatkan kinerjanya dengan tujuan untuk pengembangan karier karyawan.

Manajer atau pimpinan dapat memberikan dukungan dan penugasan yang dapat membangun bawahan untuk memotivasi pengembangan kariernya. Dengan adanya dukungan tersebut bawahan akan lebih semangat dan lebih mudah dalam mengembangkan kariernya, setidaknya bila tadinya seorang bawahan yang tidak terpikir untuk melangkah ke jenjang karier yang lebih tinggi akan mulai berpikir ke arah sana bila pimpinan terus memberikan dukungan. Penugasan yang membangun dapat menciptakan usaha yang besar dari bawahan sebagai upaya penyelesaian tugas yang jadi bagian dari tanggung jawabnya. Dengan demikian, pengalaman seseorang yang pernah menyelesaikan suatu tugas yang membuahkan hasil maksimal dapat menjadi suatu alasan bagi bawahan untuk dapat meraih jenjang karier yang lebih tinggi.

\section{Peran Organisasi dalam Pengembangan Karier}

Menurut Otte dan Hutchenson (Dessler, 2007) menyatakan bahwa peran organisasi dalam pengembangan karier berupa :

- Komunikasikan misi, kebijakan, dan prosedur.

- Sediakan pelatihan dan kesempatan pengembangan.

- Berikan informasi karir dan program karir.

- Tawarkan berbagai jenis pilihan karir. 


\section{KERANGKA ANALISIS}

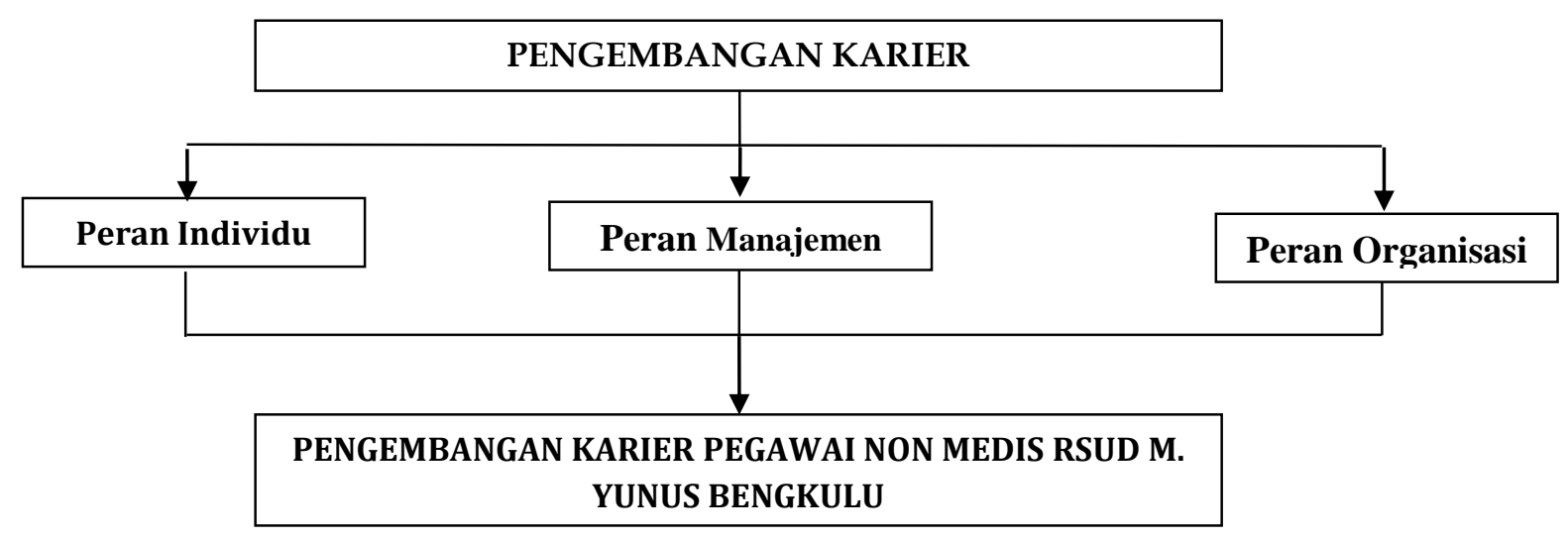

Gambar 1. Kerangka Analisis

\section{METODE PENELITIAN}

Penelitian ini menggunakan metode deskriptif kualitatif. Penelitian ini mengambil sample dari suatu populasi dan menggunakan kuisioner dan wawancara sebagai alat pengumpulan data. Penelitian dilakukan pada RSUD Dr. M. Yunus Bengkulu. Jenis penelitian ini menggunakan pendekatan deskriptif kualitatif, hasil yang diteliti difokuskan pada penggambaran kondisi lapangan mengenai pengembangan karier pegawai non medis di RSUD Dr. M. Yunus Bengkulu.

Metode pengumpulan data pada subyek penelitian ditentukan dengan menggunakan purposive sampling yaitu dari seluruh pejabat struktural di RSUD Dr. M. Yunus Bengkulu sejumlah 34 orang dan staf sejumlah 270 orang (populasi), yang akan dijadikan responden dalam penelitian adalah sebanyak 45 orang responden (sampel) dengan rincian responden yaitu Wakil Direktur (Esselon III A) sebanyak 1 (satu) orang dengan metode wawancara; Kepala Bidang \& Kepala Bagian (Esselon III B) sebanyak 1 (satu) orang dengan metode wawancara; Kepala Seksi \& Kepala Subbag (Esselon IV A) sebanyak 3 (tiga) orang dengan metode wawancara; Staf RSUD M. Yunus Bengkulu sebanyak 40 (empat puluh) orang dengan metode kuisioner.

\section{HASIL}

\section{Peran Individu}

Bedasarkan pengolahan data primer yang dilakukan mengunakkan kuesioner dapat diketahui bahwa nilai rata-rata terkecil untuk indikator peran individu menunjukkan bahwa pada RSUD M Yunus Bengkulu, rata-rata pegawai non medisnya kurang aktif dalam mencari informasi pendidikan lanjutan untuk pengembangan kariernya. Oleh karena itu diharapkan para pegawai tersebut hendaknya lebih pro aktif dalam mencari informasi pendidikan lanjutan. Sedangkan, skor rata-rata terbesar menunjukkan sebagian besar pegawai non medis RSUD Dr. M. Yunus Bengkulu mempunyai minat yang besar untuk mengembangkan karier mereka.

Selanjutnya dari hasil wawancara diperoleh aspek peran individu mempunyai peran yang besar dalam pengembangan karier pegawai. Pegawai non medis RSUD Dr. M. Yunus Bengkulu sudah melaksanakan peran individunya dengan baik dalam rangka pengembangan kariernya. Terdapat sebagian kecil pegawai non medis saja yang masih belum memaksimalkan peran individunya.

Berdasarkan olahan dari kuisoner dapat dilihat nilai mean keseluruhan sebesar 3.53 yang dapat diartikan bahwa secara keseluruhan aspek peran individu telah berlangsung dengan baik dalam pengembangan karier pegawai non medis RSUD Dr. M. Yunus Bengkulu. Hal ini didukung dengan pernyataan responden yang sebagian besar secara keseluruhan aspek peran individu telah dilakukan dengan baik, penuh kesadaran individu, dan sudah mendapat respon yang baik dari pegawai non medis RSUD Dr. M. Yunus Bengkulu dalam rangka pengembangan karier. Hanya terdapat sebagian kecil pegawai non medis yang belum menjalankan peran individunya dengan baik.

\section{Peran Manajemen}

Berdasarkan pengolahan data primer yang dilakukan mengunakkan kuesioner dapat diketahui bahwa nilai rata-rata terkecil untuk indikator peran manajemen menunjukkan pimpinan pegawai non 
medis RSUD Dr. M. Yunus Bengkulu bisa dikatakan pimpinan dianggap kurang memberikan kesempatan pada pegawai untuk mengikuti pelatihan-pelatihan dan Diklat pim agar pegawai dapat mewujudkan rencana pengembangan karir mereka. Sedangkan, skor rata-rata terbesar untuk indikator peran manajemen menunjukkan pimpinan pegawai non medis RSUD Dr. M. Yunus Bengkulu telah memberikan dukungan terhadap pengembangan karier para pegawainya, yaitu berupa kesempatan bagi pegawai yang ingin mengikuti pendidikan lanjutan.

Berdasarkan pernyataan dari kelima responden peneliti dapat menarik kesimpulan bahwa pimpinan di RSUD Dr. M. Yunus memberi kesempatan kepada pegawai untuk mewujudkan rencana pengembangan karier pegawai non medis, yaitu berupa kesempatan untuk mengikuti pelatihan-pelatihan.

Berdasarkan pernyataan diatas tentang aspek peran manajemen dalam pengembangan karier. Sebagian besar responden menyatakan bahwa aspek peran manajemen mempunyai kontribusi yang baik dalam pengembangan karier pegawai. Pihak pimpinan RSUD Dr. M. Yunus Bengkulu sudah melaksanakan peran manajemennya dengan baik dalam rangka pengembangan karier pegawai non medis. Hal ini dapat dilihat dari mean rata-rata kuisioner yang menunjukkan angka 3.45 yang dapat diartikan bahwa secara keseluruhan peran manajemen dalam pengembangan karier pegawai non medis sudah baik. Hasil kuisioner dapat didukung oleh hasil wawancara berupa pernyataan sebagian besar responden yang menyatakan secara keseluruhan peran pimpinan sebagai pihak manajemen sudah baik.

\section{Peran Organisasi}

Berdasarkan pengolahan data primer yang dilakukan mengunakkan kuesioner dapat diketahui bahwa nilai rata-rata terkecil untuk indikator peran organisasi menunjukkan penyediaan sarana diklat untuk pengembangan karier pada RSUD Dr. M. Yunus Bengkulu dinilai kurang oleh para pegawai. Sedangkan, skor rata-rata terbesar untuk indikator peran oragnisasi mengindikasikan bahwa organisasi mempunyai peran yang baik terhadap pengembangan karier pegawai non medis RSUD Dr. M. Yunus Bengkulu yaitu dengan memberikan kesempatan yang ideal kepada pegawai yang ingin mengembangkan kariernya. Berdasarkan berbagai pernyataan diatas dapat disimpulkan bahwa RSUD Dr. M. Yunus Bengkulu memberikan kesempatan yang ideal untuk semua pegawai non medis dalam rangka mengembangan karier.

Hasil wawancara mengenai pendapat responden tentang aspek peran organisasi dalam pengembangan karier dapat mewakili keseluruhan manajemen yang ada di RSUD Dr. M. Yunus Bengkulu. Pihak RSUD Dr. M. Yunus Bengkulu sudah melaksanakan peran organisasinya dengan baik dalam rangka pengembangan karier pegawai non medis. Hal ini dapat dilihat dari mean rata-rata kuisioner yang menunjukkan angka 3.45 yang dapat diartikan bahwa secara keseluruhan peran organisasi dalam pengembangan karier pegawai non medis sudah baik.

Hasil kuisioner dapat didukung oleh hasil wawancara berupa pernyataan sebagian besar responden yang menyatakan secara keseluruhan peran RSUD Dr. M. Yunus Bengkulu sudah baik. Hanya saja, RSUD Dr. M. Yunus Bengkulu masih mempunyai keterbatasan dana untuk menyediakan sarana diklat dan keterbatasan dana dalam penyediaan bantuan pendidikan lanjutan guna untuk mendukung pengembangan karier pegawai non medis.

\section{Implikasi Penelitian}

Berdasarkan temuan penelitian maka implikasi hasil penelitian adalah sebagai berikut:

1. Pengembangan karier di RSUD Dr. M. Yunus Bengkulu sangat dipengaruhi oleh peran individu, peran manajemen, dan peran organisasi. Pengembangan karier pegawai non medis RSUD Dr. M. Yunus Bengkulu pada aspek peran individu menemukan hambatan untuk menyusun tujuan dan perencanaan karier. Hal ini dikarenakan sebagian besar pegawai non medis kurang aktif dalam mencari informasi mengenai pendidikan lanjutan. Selain itu, sebagian besar pegawai non medis belum memanfaatkan kesempatan yang ada untuk mengikuti pendidikan lanjutan untuk pengembangan kariernya dikarenakan tidak adanya bantuan dana dari RSUD Dr. M. Yunus Bengkulu.

2. Ditinjau dari aspek manajemen, pimpinan masih kurang memberikan tugas yang bersifat membangun kepada pegawai non medis, misalnya menugaskan pegawai untuk mengikuti pelatihan-pelatihan sesuai dengan bidang masing-masing. belum dapat mendukung sepenuhnya pengembangan karier pegawai non medis. Namun pimpinan telah memberikan motivasi dan dukungan berupa kesempatan untuk mengikuti pendidikan lanjutan, namun masih banyak pegawai yang belum memanfaatkan kesempatan tersebut dikarenakan tidak adanya bantuan dana untuk pendidikan lanjutan bagi pegawai.

3. Pengembangan karier pegawai non medis sangat tergantung dengan kebijakan dan prosedur yang ada di RSUD Dr. M. Yunus Bengkulu. Ditinjau dari aspek peran organisasi, RSUD Dr. M. Yunus Bengkulu belum menyediakan sarana Diklat sehingga pegawai non medis masih banyak yang belum mengikuti 
Diklat untuk menunjang pengembangan karier selanjutnya. Selain itu, di RSUD Dr. M. Yunus Bengkulu belum mempunyai program khusus untuk pengembangan pegawai non medis disebabkan oleh tidak adanya pengalokasian dana khusus untuk pendidikan lanjutan.

\section{DAFTAR PUSTAKA}

Dessler, Gary., 2007, Manajemen Sumber Daya Manusia, Jilid 2, Edisi 10, Penerbit PT. Prenhallindo, Jakarta Flippo, Edwin. 1995. Personel Management. Edisi Kelima. Singapore: McGraw Hill. Inc

Gibson,dkk., 2000, Produktivitas dan Manajemen Kepegawaian, Penerbit CV. Haji Mas Agung, Jakarta

Handoko, T. Hani., 2000, Manajemen Personalia dan Manajemen Sumber Daya Manusia, Penerbit BPFE, Yogyakarta.

Harsoyo, 1997 , Manajemen Personalia dan Manajemen Sumber Daya Manusia, Penerbit BPFE, Yogyakarta. Hasibuan, Melayu, 2001. Manajemen Sumber Daya Manusia, Edisi Revisi, Penerbit Bumi Aksara, Jakarta Jhon dan Osbon, 1997, "Understanding Human Competence at Work: An Interpretative Approach", Academy of Management Journal, Vol 43, No 1, 9-25

Poerwadarminta.2000. Manajemen Kepegawaian Sipil di Indonesia, CV. Kencana Prenada Media Group, Jakarta.

Tohardi, Ahmad, 2002. Manajemen Sumber Daya Manusia. Penerbit CV. Mandar Maju, Bandung, Universitas Tanjung Pura.

Wahyudi, Bambang., 2002, Manajemen Sumber Daya Manusia, Penerbit Sulita, Bandung 